DOI: http://dx.doi.org/10.33846/hn40204

http://heanoti.com/index.php/hn

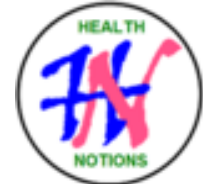

RESEARCH ARTICLE

URL of this article: http://heanoti.com/index.php/hn/article/view/hn40204

\title{
Development of Stunting Prevention Behavior Model Based on Health Promotion Model and Social Capital in The Magetan District
}

\author{
Agung Suharto ${ }^{1(\mathrm{CA})}$, Moh. Wildan ${ }^{2}$, Tinuk Esti Handayani ${ }^{3}$ \\ ${ }^{1(\mathrm{CA})}$ Department of Midwifery, Poltekkes Kemenkes Surabaya, Indonesia; \\ agungsuharto14@gmail.com (Corresponding Author) \\ ${ }^{2}$ Department of Midwifery, Poltekkes Kemenkes Malang, Indonesia; wildanjember03@gmail.com \\ ${ }^{3}$ Department of Midwifery, Poltekkes Kemenkes Surabaya, Indonesia; tinukesti@gmail.com
}

\begin{abstract}
Stunting was a chronic malnutrition problem that is caused by a lack of nutrition in a long time due to food that is not in accordance with nutritional needs. The purpose was to prove the development of a health promotion model and social capital in improving the behavior of mothers of to toddlers in stunting prevention. Phase 1 were cross sectional, with multistage sampling, size 300 people. Exogenous variables were health promotion model and social capital, endogenous variables: stunting prevention behavior. Phase 2 were quasy experiment, sample size 100 people were 2 groups: intervention and control. Data analysis were descriptive analysis and multivariate analysis: CFA, SEM and T-Test. Phase 1 were significant (T-value > 1.96), namely prior related behavior, personal factor, perceived self efficacy, activity related affect. Social capital variables significant was participation. Stage 2, intervention mean was higher than control. Independent $T$ Test post test of the intervention and control groups with results $\mathrm{p}=0.00(\mathrm{p}<0.05)$ there were significant. Conclussion: the development of a health promotion model based on stunting prevention health promotion models and social capital has been to improved maternal behavior regarding stunting prevention.
\end{abstract}

Keywords: health promotion model; social capital; stunting

\section{INTRODUCTION}

\section{Background}

Stunting arises as a result of long-standing conditions such as poverty, improper parenting behaviors, and often suffering from recurrent disease due to poor hygiene and sanitation ${ }^{(1)}$. Stunted toddlers have a risk of decreased intellectual ability, productivity, and increased risk of degenerative diseases in the future ${ }^{(2)}$. Therefore Stunting in infancy needs special attention, including children aged 2-3 years. The growth process at the age of 2-3 years tends to slow down so that the chances of catching up to grow are lower than those of 0-2 years. Age 2-3 years is the age of the child experiencing rapid development in cognitive and motor skills. Maximal physical conditions are needed to support this development, where in children who are stunted the development of motor and cognitive abilities can be disrupted ${ }^{(3,4)}$.

Indonesia was ranked fifth in the world for the number of children with stunting. More than a third of children under the age of five in Indonesia are below average height. In fact, stunting cases in Indonesia are increasing. Global stunting toddler data in 2016 was $22.9 \%$, Indonesian data in 2017 was 29.6\%. East Java data: 2012 32.7\%, 2017 29.6\%. Whereas the data in Magetan Regency: in 2013 was 27.9\%, in 2015 it was 22.4\% and in 2017 it was $24.8 \%^{(5)}$. 


\section{Purpose}

Proving the development of health promotion models based on stunting prevention behavior and social capital influence in improving the behavior of mothers of toddlers in stunting prevention.

\section{METHODS}

Research phase 1,with a cross sectional design, the population of the study of mothers of children under five in the area of health centers in Magetan Regency in 2018 was 36,780 people. Sampling technique: multistage sampling, sample size to 300 mothers of toddlers ${ }^{(6)}$. Exogenous variables are prior related behavior, personal factors (customs, habits, culture). Endogenous variables in this study are perceived benefit of action, perceived barrier of action, perceived self efficacy, activity related affect, interpersonal influences (family, peers, providers, norms, support, models), situation influences (option demand, characteristic aesthetic), Immediates competing demands (low control) and preferences (High control), Committment to a plan of action, health promoting behavior. Descriptive analysis and confirmatory factor analysis (CFA) and structural equation modeling (SEM) with the Lisrel $8.7 \operatorname{program}^{(7)}$.

Research phase II: Quasy experiment with non equivalent control group pretest-posttest design ${ }^{(8)}$. The research locations were "Posyandu Melati 1" Milangasri Village Panekan District Magetan District Panekan Puskesmas area as a case and "Posyandu Melati 2" Milangasri Village Panekan District Magetan District Panekan Puskesmas area as controls. Population of 100 people. "Posyandu Melati 1" Milangasri, Panekan District, Magetan Regency are 50 people. The group that was not given treatment (control) was "Posyandu Melati 2" Milangasri Village, Panekan District, Magetan Regency as many as 50 people. The independent variable in this study is a module about developing a stunting prevention behavior model based on Health promotion model and social capital. The dependent variable is the behavior of mothers of toddlers in stunting prevention. Data analysis Descriptive analysis and statistical analysis Paired $\mathrm{T}$ Test and Independent $\mathrm{T}$ Test. with a probability of $0.05^{(9)}$.

\section{RESULTS}

\section{Age, Education and Occupation}

Table 1. Distribution of respondent's age, education and occupation

\begin{tabular}{cccc}
\hline No & Age (years) & Frequency & Percentage \\
\hline 1 & $16-20$ & 13 & 4.3 \\
2 & $21-25$ & 65 & 21.7 \\
3 & $26-30$ & 79 & 26.3 \\
4 & $31-35$ & 105 & 35 \\
5 & $36-40$ & 38 & 12.7 \\
\hline & Total & 300 & 100 \\
\hline No & Education & Frequency & Percentage \\
\hline 1 & Basic & 105 & 35 \\
2 & Intermediate & 174 & 58 \\
\hline 3 & High & 21 & 7 \\
\hline & Total & 300 & 100 \\
\hline
\end{tabular}




\begin{tabular}{cccc}
\hline No & Employer & Frequency & Percentage \\
\hline 1 & Housewife (IRT) & 165 & 55 \\
2 & Private / entrepreneur / farmer & 122 & 40.6 \\
3 & Government employees/ Army / Police & 13 & 4.4 \\
\hline & Total & 300 & 100 \\
\hline
\end{tabular}

\section{Confirmatory Factor Analysis}

Table 2. The results of confirmatory factor analysis

\begin{tabular}{clcl}
\hline No & \multicolumn{1}{c}{ Correlation research indicators } & Significance & Information \\
\hline 1 & Health promotion model with prior related behavior & 3.18 & Significant \\
\hline 2 & Health promotion model with personal factor & 5.22 & Significant \\
\hline 3 & Health promotion model with perceived benefit of action & 1.01 & No significant \\
\hline 4 & Health promotion model with perceived self eficacy & 5.55 & Significant \\
\hline 5 & Health promotion model with activity related affect & 4.34 & Significant \\
\hline 6 & Health promotion model with interpesonal influences & 1.30 & No significant \\
\hline 7 & Health promotion model with situation influences & 0.68 & No significant \\
\hline 9 & Health promotion model with commitmen plan of action & -0.52 & No significant \\
\hline 10 & Social capital with proactive & 2.17 & Significant \\
\hline 11 & Social capital with network & -0.24 & No significant \\
\hline 12 & Social capital with recyprocal & -1.66 & No significant \\
\hline 13 & Behavior with immediate & -0.67 & No significant \\
\hline 14 & Behavior with regularity & 5.64 & Significant \\
\hline 15 & Behavior with sustainability & 8.43 & Significant \\
\hline & & 9.24 & Significant \\
\hline
\end{tabular}

\section{Goodness of Fit (GoF)}

To assess the validation of the prediction of the model as a whole can be seen with the Goodness of Fit value which includes: Chi Square, Probability, RMSEA and GFI. From the SEM analysis results obtained Chi square values (CMIN): 109.80; Probability value: 0.074; RMSEA: 0.99 and GFI value: 0.95. From this value, then the behavior model can be stated fit and significant.

\section{Structural Equation Modeling (SEM)}

To find out the effect of exogenous variables on endogenous variables, statistical tests are performed using Structural Equation Model (SEM) analysis with the LISREL 8.7 program. From the SEM results, we will get a significant or insignificant factor. The influence of this significant factor will be used as a basis for developing models that will be intervened in modules to research respondents. SEM analysis can be seen in the image below: 


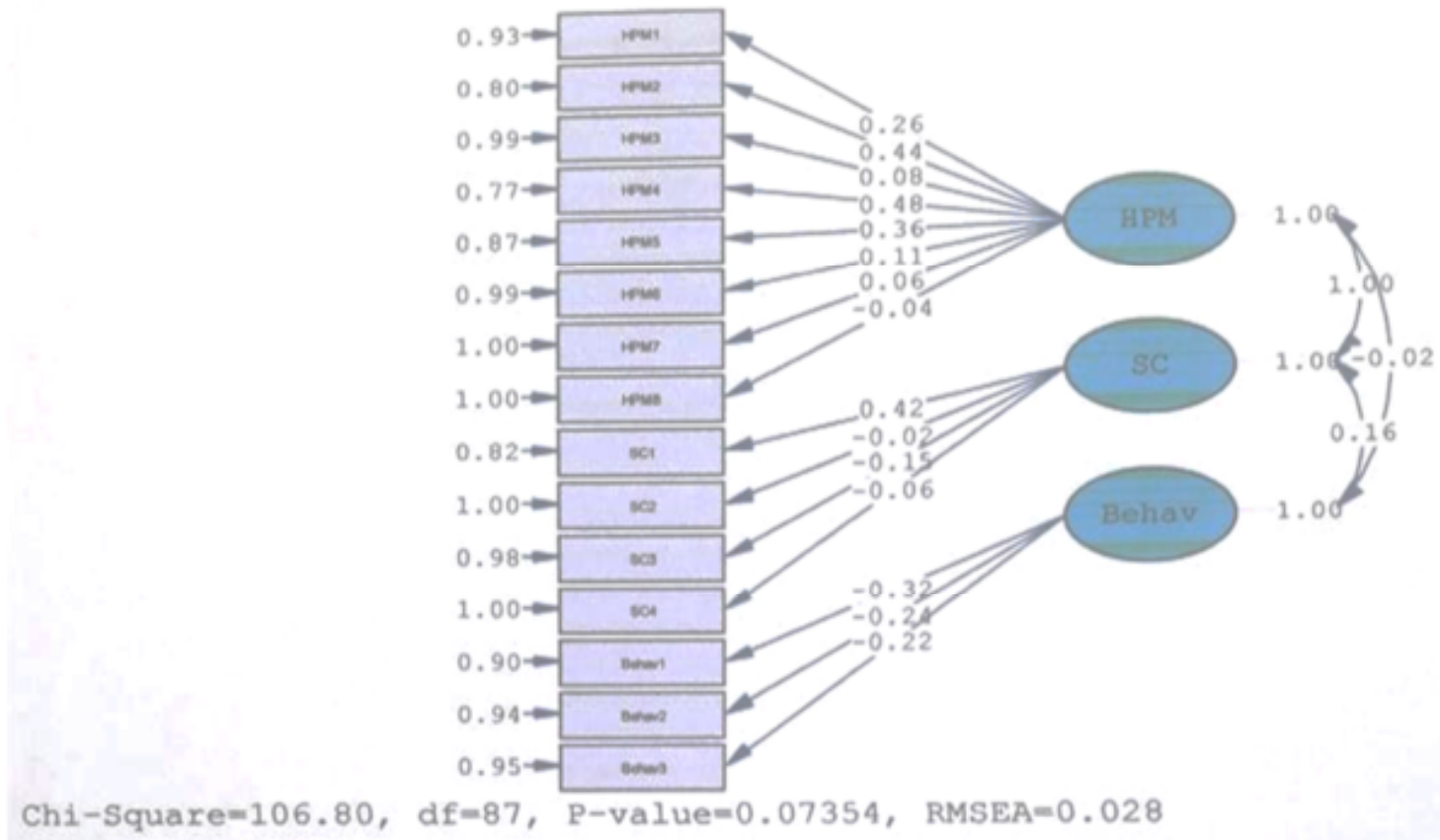

Figure 1. Structural equation modeling (SEM): standardized estimates

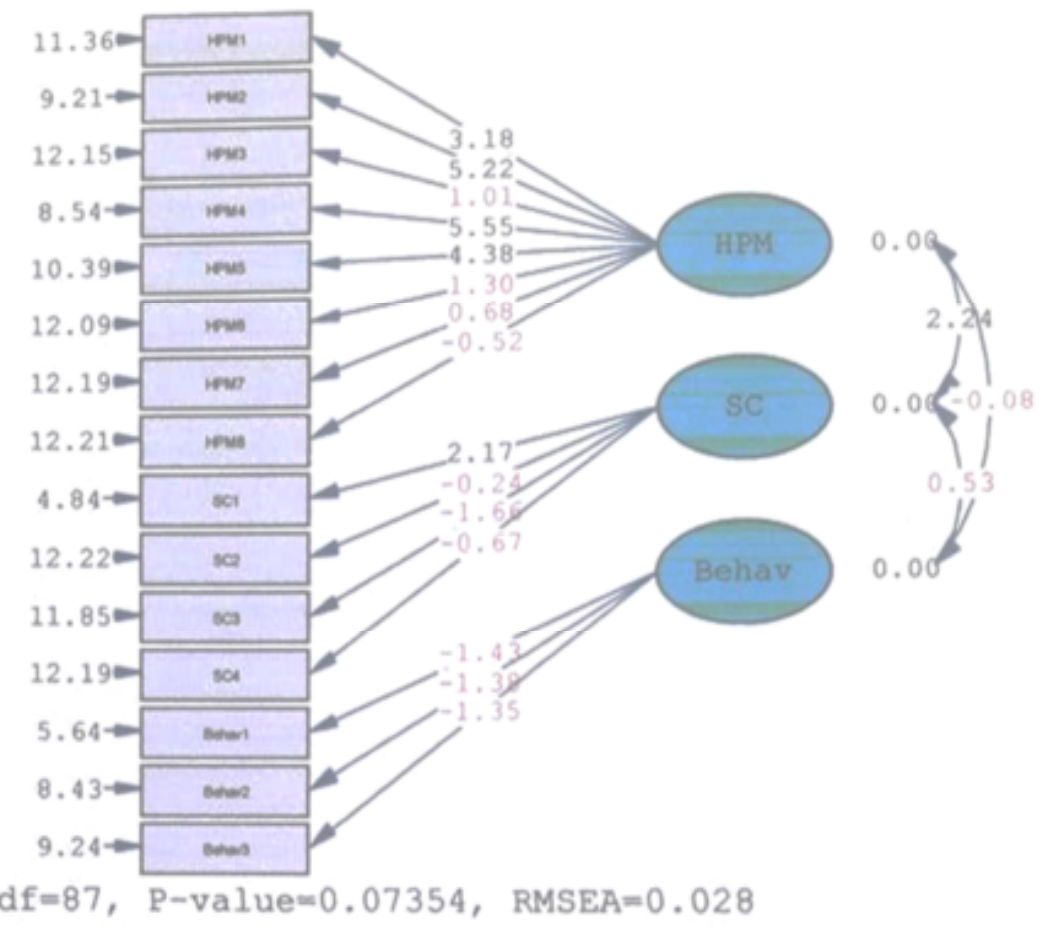

Figure 2. Structural equation modeling (SEM): T-value 


\section{Development of A Stunting Prevention Model}

From the final analysis of the Structural Equation Model (SEM) using LISREL 8.7 the final Structural Equation Modeling (SEM) test results on the causal relationship of research factors found 8 valid and significant relationships including health promotion models and social capital influencing behavior (stunting prevention behavior) ) in Magetan Regency.

\section{Recommended focus group discussion (FGD) results}

To complete the intervention model that was compiled based on the results of phase 1 research, a Focus Group Discussion with relevant stakeholders was conducted. From the results of the Focus Group Discussion (FGD) with the Head of the Magetan District Health Office, the Head of the Family Health Section of the Magetan District Health Office, the Head of the Maospati Health Center, the Head of the Takeran Health Center, the Head of the Panekan Health Center and the Head of the Plaosan Health Center, the Coordinating Midwife and the Penang MIA and Nutrition Health Office in Magetan Regency which was held on Monday July 1, 2019 at the Magetan District Health Office, the following recommendations were agreed:

1. Health Promotion Model, is a health promotion model that is very needed in providing health education to the community, including prevention of stunting in infants. The recommendations given from the FGD are:

a. Health promotion on stunting prevention can be done in every activity in the community, for example: "posyandu", "posbindu", meetings and PKK activities.

b. Health promotion activities on stunting prevention in Magetan Regency can be carried out in an integrated manner with the Mayangsarri Program (Magetan Dear Teen Mothers and Babies).

c. Stunting prevention health promotion activities can also be carried out together with counseling activities for healthy and alert villages.

2. Social capital, is social capital that is very much needed in the behavior of visiting mothers in preventing stunting through the posyandu program. Recommendations as follows:

a. Increasing community participation and mothers of children under five is very necessary in the implementation of posyandu activities, in the form of activities in visiting posyandu in efforts to prevent stunting.

b. The activeness of the community and mothers of children under five is very necessary in the implementation of posyandu activities, in the form of activities in visiting posyandu to detect early stunting events.

c. Need to improve community partnerships with mothers of toddlers in the implementation of posyandu activities, in the form of partnerships between mothers of toddlers and posyandu officers so that the incidence of stunting can be known early.

d. Reciprocal relationship between the community and mother of children under five is very necessary in the implementation of posyandu activities, so that the incidence of stunting under five can be known early.

3. Advocacy / Stunting Management Policy at Magetan Regency level:

The establishment of the Food and Nutrition Alert Task Force in stunting prevention in Magetan Regency, based on the Decree of the Magetan Regent of East Java Number: 188/159 / Kept. / 403.013 / 2018, dated July 11, 2018.

\section{Descriptive Analysis of Variables}

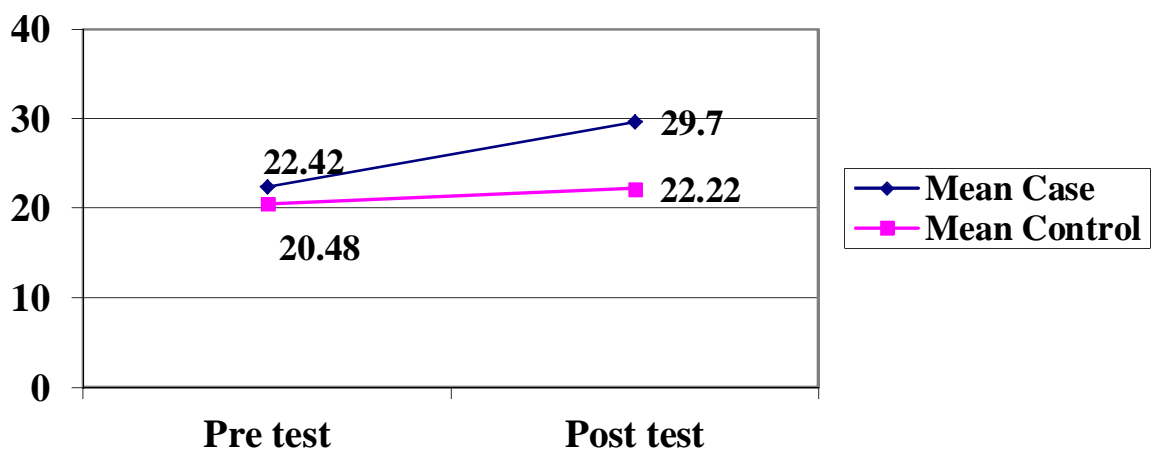

Figure 3. Difference in the increase in mean pre-test and post-test in the case group and control behavior of stunting prevention in Magetan Regency 2019 


\section{Inferential Analysis}

$\underline{\text { Paired sample T test }}$

Table 3. The results of paired sample T test

\begin{tabular}{ccccccc}
\hline Pre test-post test & $\begin{array}{c}\text { Std. } \\
\text { deviation }\end{array}$ & $\begin{array}{c}\text { Std. Error } \\
\text { Mean }\end{array}$ & T & Df & $\begin{array}{c}\text { Sig. } \\
(2- \\
\text { tailed })\end{array}$ & Information \\
\hline Casus & 3.876 & 0.548 & -13.282 & 49 & 0.000 & Significance \\
\hline Control & 1.275 & 0.180 & -9.652 & 49 & 0.000 & Significance \\
\hline
\end{tabular}

$\underline{\text { Independent sample T test }}$

Table 4. The results of independent sample T test

\begin{tabular}{ccccccc}
\hline & $\begin{array}{c}\text { Mean. } \\
\text { difference }\end{array}$ & $\begin{array}{c}\text { Std. Error } \\
\text { difference }\end{array}$ & T & Df & $\begin{array}{c}\text { Sig. } \\
\text { (2-tailed) }\end{array}$ & Information \\
\hline $\begin{array}{c}\text { Post test Case- } \\
\text { control }\end{array}$ & 7.480 & 0.526 & 14.229 & 98 & 0.000 & Significance \\
\hline
\end{tabular}

\section{DISCUSSION}

Prior related behavior and personal factors (biological, psychological, socio cultural) (customs, habits, culture) affect the perceived benefit of action (the perceived benefits of action) of toddlers in the prevention of stunting obtained the value of $\mathrm{T}=3.18$ ( $\mathrm{T}$ Value) $>1.96$ ). It can be concluded that there are influences of Prior related behavior and personal factors (biological, psychological, socio cultural) (customs, habits, culture) to the perceiveed benefit of action (the perceived benefits of action) of toddlers in preventing stunting in Magetan Regency. Interaction theory models that include environment, humans and behaviors that influence each other. This theory emphasizes: self direction (self direction), self regulation (self regulation), perception of self progress (self efficacy). This theory suggests that humans have the basic abilities: a. Symbolization is the process and transformation of experience as a guide for future actions; b. Thinking ahead, anticipating events that will arise and planning actions to achieve quality goals; c. Learn from other people's experiences. Establish rules for generation and regulate behavior through observation without the need for trial and error; d. Selfregulation uses internal standards and self-evaluation reactions to motivate and regulate behavior, regulating the external environment to create motivation in action; e. Self-reflection, think about one's thought processes and actively modify them ${ }^{(10)}$.

Prior related behavior and personal factors (biological, psychological, socio cultural) (customs, habits, culture) affect the perceiveed barrier of action (perceived obstacle of action) of toddlers in the prevention of stunting obtained the value of $\mathrm{T}=5.22$ ( $\mathrm{T}$ Value> 1.96). It can be concluded that there are influences of Prior related behavior and personal factors (biological, psychological, socio cultural) (customs, habits, culture) to the accelerated barrier of action (obstacle perceived from action) of toddlers in preventing stunting in Magetan Regency. According to this theory self-confidence is formed through observation and self-reflection. Selfconfidence consists of: 1 . Self-introduction (self attribute); 2. Self evaluation (self evaluation); 3. Self-efficacy (11). Self-improvement is one's ability to perform certain actions that develop through experience, learning from other experiences, verbal persuasion and bodily responses to certain situations. Self-improvement is a function of excessive capability that forms competence and self-confidence. Progress is the central construction of $\operatorname{HPM}^{(12)}$

Prior related behavior and personal factors (biological, psychological, socio cultural) (customs, habits, culture) affect the perceived self-efficacy (perceived self-efficacy) of toddlers in the prevention of stunting obtained the value of $\mathrm{T}=1.01$ ( $\mathrm{T}$ Value $<1.96$ ). It can be concluded that there is no influence of Prior related behavior and personal factors (biological, psychological, socio cultural) (customs, habits, culture) to the 
accelerated self-efficacy (perceived self-efficacy) of toddlers in preventing stunting in Magetan Regency. Self efficacy as defined by Bandura is a judgment / decision of one's capability to organize and carry out real actions. Judgments from personal efficacy are distinguished from expectations within goals. Perceived self-efficacy is the judgment of the ability to resolve a definite level of performance, where the goal or expectation is a judgment of a consequence (for example benefits and costs) as much as the behavior will result. Perception of skills and competencies in the domain Individual motivation to involve the behaviors they go through. Feelings of efficacy and skills in one's performance seem to encourage to involve / carry out more behavior than careless and unskilled feelings ${ }^{(13)}$

Prior related behavior and personal factors (biological, psychological, socio cultural) (customs, habits, culture) affect the activity related effect (influence of related activities) of toddlers in preventing stunting, the value of $\mathrm{T}=5.55$ ( $\mathrm{T}$-value $>1.96$ ). It can be concluded that there are influences of Prior related behavior and personal factors (biological, psychological, socio cultural) (customs, habits, culture) on activity related effects (influence of related activities) of toddlers in preventing stunting in Magetan Regency. This activity-related effect differs from the evaluation dimension of the attitude expressed by Fishbein and Ajzen. The dimension of evaluation of attitudes reflects affective evaluation of the specific results of a behavior rather than the response to the stimulus nature of the behavior itself. For some of the behaviors given, the full range of negative and positive feelings must be described so that both can be measured accurately. In some instruments for measuring affect, negative feelings are described more broadly than positive feelings. This is not surprising because anxiety, fear and depression have been studied more than feeling happy, happy and calm ${ }^{(14)}$.

Prior related behaviors and personal factors (biological, psychological, socio cultural) (customs, habits, culture) affect the interpersonal influences (family, peers, providers, norms, support models) of toddler mothers in stunting prevention, the results obtained $\mathrm{T}=4.38$ ( $\mathrm{T}$-value $>1.96$ ). It can be concluded that there are influences of Prior related behavior and personal factors (biological, psychological, socio cultural) (customs, habits, culture) on Interpesoonal influences (family, peers, providers, norms, support models) of toddlers in preventing stunting in Magetan Regency. According to HPM, interpersonal influence is an awareness of behavior, beliefs or attitudes towards others. This awareness can or cannot be in accordance with reality. The main sources of interpersonal influence on health promotion behavior are family (parents and siblings), friends, and health care workers. Interpersonal influences include: norms (expectations of people who matter), social support (instrumental and emotional encouragement) and modeling (learning through observing a person's particular behavior). These three interpersonal processes in a number of health studies appear to predispose a person to carry out health promotion behavior ${ }^{(15)}$. Social norms form implementation standards that can be used or rejected by individuals. Social support for a behavior provides sources of support provided by others. Modeling describes the next component of health behavior and is an important strategy for behavior change in social cognitive theory. Interpersonal influences affect health promotion behavior directly or indirectly through social pressure or encouragement for commitment to action plans ${ }^{(16)}$.

Prior related behavior and personal factors (biological, psychological, socio cultural) (customs, habits, culture) affect the Situation Influences (option demand, aesthetic characteristics) of toddlers in stunting prevention, the significance value of $\mathrm{T}=1.30$ ( $\mathrm{T}$ Value) <1.96). It can be concluded that there is no effect of Prior related behavior and personal factors (biological, psychological, socio cultural) (customs, habits, culture) on Situation Influences (option demand, aesthetic characteristics) of toddlers in preventing stunting in Magetan Regency ${ }^{(17)}$.

The influence of social capital (participation, activeness, partnership and reciprocity) influences the behavior of mothers of children under five in preventing stunting. the results obtained value of $\mathrm{T}=2.17(\mathrm{~T}$ Value> 1.96). It can be concluded that there is an influence of social capital (participation, activeness, partnership and reciprocity) in improving the behavior of mothers of children under five in preventing stunting. Social Capital is different from other capital. If human capital can be seen and measured from the knowledge and skills possessed by a person, social capital can only be felt from capabilities that arise from general trust in a society or its parts. Social capital is transmitted through cultural mechanisms, traditions or historical habits. Social capital is needed to create a moral community that cannot be obtained or formed as in the formation of human capital. The cultivation and development of social capital requires familiarizing with the moral norms of a community and in its context while simultaneously adopting virtues such as honesty, loyalty and independence ${ }^{(18)}$.

The development of a health promotion model based on health promotion models and social capital influential in improving maternal behavior about stunting prevention results in the value of $\mathrm{T}=5.64$ ( $\mathrm{T}$ Value $>$ 1.96). It can be conc luded that there is an influence on the development of a health promotion model based on health promotion models and social capital in improving maternal behavior regarding stunting prevention.Health behavioral behavior: variables in this model have been addressed extensively through books so here requires a little further discussion. Health promotion behavior is the end point or result of action on HPM. However it must be noted that health promotion behavior is ultimately aimed at directly achieving positive health for the client. 
Health promotion behavior, especially when integrating into a healthy lifestyle that covers all aspects of life, results in positive health experiences throughout the life process ${ }^{(19)}$.

\section{CONCLUSION}

The development of stunting prevention behavior models based on health promotion models and social capital has an effect on improving maternal behavior regarding stunting prevention. Increased behavior of the intervention group (cases) was higher than the case group. This proves that significantly health promotion based on health promotion model and social capital further increases stunting prevention behavior among mothers of children under five in Magetan Regency ${ }^{(20)}$.

Recomendation with a good knowledge of mothers about stunting, mothers of toddlers will be more active in detecting early and preventing family members who have children so that toddlers do not become stunting, the community can detect early prevention of stunting in children under five and healthy lifestyle and eating, can use a health promotion model based on the Health Promotion Model and Social Capital in preventing stunting in carrying out health service tasks for families with children under five so that stunting does not occur, increase the repertoire of knowledge and as input or reference material for further research, especially health promotion.

\section{REFERENCES}

1. Health Ministry of The Republic of Indonesia. Balanced Nutrition Guidelines (Pedoman Gizi Seimbang). Jakarta: Health Ministry of The Republic of Indonesia; 2014.

2. Health Ministry of The Republic of Indonesia. Mother and Child Health Book (Buku Kesehatan Ibu dan Anak). Jakarta: Health Ministry of The Republic of Indonesia; 2015.

3. Health Ministry of The Republic of Indonesia. A Pocket Book on Monitoring Nutrition Status in 2017 (Buku Saku Pemantauan Status gizi tahun 2017). Jakarta: Health Ministry of The Republic of Indonesia; 2017.

4. Health Ministry of The Republic of Indonesia. Integrated stunting handling in 2018 (Penanganan stunting terpadu pada tahun 2018). Jakarta: Health Ministry of The Republic of Indonesia; 2018.

5. Kuntoro. Statistical Method (Metode Statistika). Surabaya: Pustaka Melati; 2011.

6. Kuntoro. Sampling Method and Determination of Sample Size (Metode Sampling dan Penentuan Besar Sampel). Surabaya: Pustaka Melati; 2010.

7. Arikunto S. Research Procedure: A Practice Approach (Prosedur Penelitian Suatu Pendekatan Praktek). Jakarta: Rineka Cipta; 2010.

8. Notoatmodjo S. Health Research Methodology (Metodologi Penelitian Kesehatan). Jakarta: Rineka Cipta; 2010.

9. Nursalam. Concepts and Application of Nursing Research Methodologies: Guidelines for Undergraduate Thesis, Thesis and Nursing Research Instruments (Konsep dan Penerapan Metodologi Penelitian Ilmu Keperawatan Pedoman Skripsi, Tesis dan Instrumen Penelitian Keperawatan). Jakarta: Salemba Medika; 2012.

10. Martin G, David AS, Benno T. The Role of Social Capital in Reducing Negative Health Outcomes among Police Officers. International Journal of Social Inquiry. 2010;3(1):141-161.

11. Pretty J, Smith D. Sosial Capital in biodeversity conservation and management. Consevation Biology. 2003;18:631-638

12. Pretty J, Ward H. Sosial Capital and The Environment. World Development. 2001;29(2).

13. Suharto A, Soedirham O, Dyson. The Influence of Factors in Social Capital on the Behavior of Mothers to Visiting "Posyandu" Park. DIJR. 2016.

14. WHO. Miles Stones in Health Promotion WHO. Geneva: WHO; 2009.

15. Yamaguchi1 A. Impact of Social Capital on the Psychological Well-Being of Adolescents International Journal of Psychological Studies. 2013;5(2).

16. Bourdiau P, Wacquant L. An Invitation to Reflexive Sociology. Chicango: University of Chicango Press; 1992.

17. Conner M, Norman P. Predicting Health Behavior. Search and Practice with Social Cognition Models. Ballmore: Buckingham: Open University Press; 1996.

18. Glanz FM, Rimer BK, Viswanath K (Eds.). Health Behavior and Health Education: Theory, Research and Practice. San Francisco: Jossey-Bass; 2016.

19. Glanz K, Rimer BK, Lewis FM. Health Behavior and Health Education: Theory, Research and Practice. San Fransisco: Wiley \& Sons; 2002. 
20. Hung T. Integrating Social Capital Theory, Social Cognitive Theory, and the Technology Acceptance Model to Explore a Behavioral Model of Telehealth Systems. Int. J. Environ. Res. Public Health. 2014;11. 